\title{
We are Sweden Democrats because we care for others: Exploring racisms in the Swedish extreme right
}

\author{
Diana Mulinari and Anders Neergaard
}

\section{Linköping University Post Print}

\section{Tweet}

N.B.: When citing this work, cite the original article.

Original Publication:

Diana Mulinari and Anders Neergaard, We are Sweden Democrats because we care for others: Exploring racisms in the Swedish extreme right, 2014, The European Journal of Women's Studies, (21), 1, 43-56. http://dx.doi.org/10.1177/1350506813510423

Copyright: SAGE Publications (UK and US) http://www.uk.sagepub.com/home.nav

Postprint available at: Linköping University Electronic Press http://urn.kb.se/resolve?urn=urn:nbn:se:liu:diva-105759 


\section{Introduction}

During the last decades there has been an upsurge in research on xenophobic populist parties mirroring the political successes of these parties in Western Europe and to some extent in Eastern Europe. In the Swedish context, in a period of neoliberal restructuring of the welfare state, not only have issues of 'race', citizenship and belonging been important elements of the public debate, but these issues have unfolded in parallel with the presence of a neo-Nazi social movement and the emergence of two new parliamentary parties - New Democracy from 1991 to 1994 and Sweden Democrats (SD) from 2010 - in which cultural racism has been central (Deland and Westin, 2007).

Mainstream research has especially focused on the xenophobic content and how to relate these parties to the wider research on party politics in Western liberal democracies. While there have been some studies emphasising the fact that women to a lesser degree than men vote and participate in these parties, there are still very few studies analysing the worldview of women active in these parties, and the role of gender as metaphor, identity and as policy within these parties.

The aim of the article is to explore how women within a Swedish version of these parties, the Sweden Democrats, name and reflect upon their experiences, especially focusing on how a care rhetoric is used in their narratives. ${ }^{1}$ Many of our female informants claim that there is a big challenge in being a representative for the SD. They can be ostracised by other political parties and labelled racist by the media, neighbours and friends. Family members may

\footnotetext{
${ }^{1}$ The study is inspired by a qualitative methodology. The material consists of twenty interviews with SD representatives in 2008-2009, participant observation in three municipality budget debates and text analysis of party documents and SD's blog. The informants were never asked questions on racism, migrants and ethnicity, but the informants raised such issues as responses to general questions.
} 
consider their political choice objectionable. Following the electoral success of the Sweden Democrats there have been discussions among the other parties in the national parliament on strategy. So far all parties have declared that they do not negotiate politics with SD. Thus, the women we interviewed have chosen to represent a racist party (although they do not see themselves or the party as racist). What inspires them? What visions of gender evolve from their worldview?

We take as our point of departure twenty in-depth interviews with female SD politicians from both 'majority' and migrant backgrounds complemented by party texts and participant observation. Our personal location (as non-white scholars) provides, we think, a different base for alternative understandings, compared to that offered by mainstream political science and sociology that, we argue, both conceals the centrality of racisms and under-theorises gender. We do not, however, see our study as the only answer; it is a partial interpretation that, hopefully, contributes to a wider understanding (Blee and Kenny, 2000).

The article is structured in the following way. We start by outlining the context of our study, focusing on culturally racist parties and specifically Sweden and the Sweden Democrats. Thereafter we give some illustrations of the ways in which the Sweden Democrats act upon notions of gender and gender equality. The main focus of the article explores the central role that notions of care have in the accounts of female SD activists. We conclude by arguing the need for a feminist and race-critical exploration (Lewis, 2006, Essed, 2001) of the tensions between gendered notions of care and gendered racism.

\section{Exploring culturally racist political parties}


There is a plethora of names being used to describe parties that, as a central mobilising interpellation, focus on the threats of migration, migrants and racialised others. Extreme Right (Mudde, 2000), Extreme Right-Wing Populism (Rydgren, 2005a), Radical Right-Wing Populism (Rydgren, 2005b), Populist Parties of the Right (Betz, 2005) and Populist Radical Right Parties (Mudde, 2007) are some of the terms used to describe such parties. Instead of using the word 'racism' these researchers often talk about migration sceptics, anti-migration, welfare-chauvinism, nativism and xenophobia. Inspired by Fennema (1997) and the discussion of new/cultural racism (Barker, 1981), we conceptualise the Sweden Democrats as a culturally racist party. The concept of racism aims to emphasise the diverse forms of racist ideology and its structuration in specific historical circumstances (Balibar, 1991, Gilroy, 2004) and lends itself to an understanding both of traditional biological racism and new or changing forms of racism (Bhavnani, 2001, Feldman, 2011). One central feature in these understandings is that racism is increasingly expressed in ways that do not use the word 'race' as a word. However, ethnicity, culture and religion are used in a racialising manner that often recreates the content of biological racism through different words. This cultural racism, we argue, characterises the Sweden Democrats.

In capturing racism in society, there has been an emphasis on the racism oh the extreme-right parties. However, we differentiate between two forms of racism - exclusionary and exploitative (Mulinari \& Neergaard 2012a). We see exclusionary racism (that can also be called the losers' racism) as associated with the radical right-wing party political idea of 'getting rid of them'. Exploitative racism (that can also be called the winners' racism), in contrast, is about creating a labour force that can be used for low-paid work (Miles, 1987, 
Castles and Kosack, 1973), and is a central aspect in the global reproduction of capitalism in its neoliberal form and thus located in the centre of society (Lutz, 2011, Phizacklea, 2004). What is interesting to note is that parts of the racialising discourses are similar while others are quite distinct, but more importantly they are invoked for completely different political projects.

Thus, SD's cultural racism may to a certain extent be seen as an extreme reworking of notions and practices that are embedded in European liberal democracies (Perry, 2001). They reproduce and develop hierarchies between groups that are already established. The radicality lies in how they present solutions and, through these solutions, develop their variant of racism. Our contention is that the hegemonic Swedish public and political discourse already contains similar (racist) elements, in moderate forms (Hellström and Nilsson, 2010).

These different forms of racism have also different intersections of gender and racism. Exploitative racism focuses on the construction of (cheap) labour through racialisation, as well as reaping tax benefits for employing (migrant) domestic workers. And while racialisation is used in respect of both men and women, it is gendered in the construction of exploitable labour. In a Swedish context, the technique used has mainly been to construct migrant women as care labour in both public and private sectors (Gavanas, 2010). In contrast, exclusionary racism, a hallmark of the SD, is woven into a particular (exclusionary) gender discourse based on the regulation of sexuality and reproduction within the nation, the protection of 'our' women, and the inferiorisation/demonisation of 'the Other"s gender culture (Yuval-Davis and Marfleet, 2012, Blee, 2007, Koonz, 1987).

Despite the gendered character of how cultural racism is articulated there is still very little research focusing on parties like the Sweden Democrats A point of departure for this article is 
the strong underrepresentation of women within Sweden Democrats. While SD has a membership of over 9,000 members, only about $20 \%$ are women. Furthermore, women account for only $15 \%$ of SD 's national parliamentarians (the second-lowest representation of women is in the Centre Party, with about a third); in regional and local municipalities the representation is slightly higher (17\% and 19\%). The estimation (from exit and opinion polls) of the female vote is around a quarter to a third, and it is not increasing. This is in line with voting patterns in other European countries. However, when it comes to opinions on migrants and migration, Swedish women are generally more in favour of migration and migrants (Mella and Palm, 2013), while there is, according to Mudde, little gender difference in most other countries (2007).

In the analyses of our interviews, the SD women seem to be bearers of a particular form of femininity (Martin, 2001, Rose, 2005) that is difficult to reconcile with the Swedish discourse on gender equality, rooted as it is in women's equal participation in the labour market (most of our informants are unemployed, on sick-leave and lack a professional/work identity) on the one hand, and double-income households on the other - a discourse that is central for women politicians in all Swedish parties from the Left to Right. Their marital status (where many are divorced, single mothers or with no children) may have decreased their identification with the Christian Democrats, the only party in the Swedish parliament that shares their views about gender, although without the element of cultural racism. In this sense women's activism could be understood as a strategy to mobilise the only capital (Adkins, 2001) they have left: their Swedishness. We say 'Swedishness', but should say 'whiteness/Europeanness' as some of our informants have migrated from other European countries. The class composition of SD 
activists varies, although generally there is an overrepresentation of working class and small business owners, often on the margins of being established. Most of our informants could be described as unskilled workers at the margin of the labour market, often relying at least partially on social insurance/benefits. However, those of the leadership who are universityeducated have played an important role in trying to change the appearance of the party towards a more cultivated posture, while attempting to maintain the underdog position vis-àvis all the other parties defined as the elite.

\section{Sameness for the nation, difference for the family}

We reject the attempts to adapt mankind to magnificent utopias. Instead, we believe that politics should be elaborated according to how mankind is in reality. Every society should be built on shared values, the lowest common denominator of basic norms and values.... Sure, every person is unique, but we are also more or less similar. We are all dependent on solidarity, people who in various ways are similar to us and that we can identify with. Sweden Democrats believe that it is primarily the family and the nation that give us the conditions to achieve this. No constructed collective can fully replace these deeply rooted, original senses of belonging (Sverigedemokraterna 2005).

Men and women are not created equal and can, therefore, in different contexts use different starting points and do different things in different ways. Men and women complement each other, and, therefore, every child's right to a mother and a father is also of substantial significance (Sverigedemokraterna 2005). 
The above quotes do not touch on migration or criticise Swedish gender equality policies.

They do not discuss biology or race. The emphasis is on how people really are. The SD's

political profile uses common-sense understandings and the term 'real people' ${ }^{2}$ to create a representation of the party as embodying the true feelings of the common man, the one who 'knows' that women and men are different and loves his family but not his neighbours (if they are not similar to himself). There is, however, a tension in how the racist worldview of the party understands human nature. While the nation as a natural place for solidarity is characterised by similarity, the family in general and particularly the close relationship between women and men is characterised by complementarity. While sameness is fundamental to belonging to the nation, difference (between women and men) is the nucleus for regulating intimacy and kinship systems.

The SD's 2010 election program, argues Norocel (2013), uses the word 'protect' in relation to both (Swedish) children and demanding jobs for (Swedish) workers, so that men are once again able to provide for their families. This re-inscription of patriarchal order that is at the heart of men's support of the party, this nostalgia for what has been lost was however not very marked in our interviews with women activists.

Per Björklund, member of the party executive, party treasurer and municipal policy coordinator stresses the link between curtailing women's rights and reproducing the nation when talking about abortion:

\footnotetext{
2 Playing on the antagonism between 'the people' and the elites, the term 'Real People' was used in Sweden by the right-wing populist party New Democracy in the early 1990s, but is also actively used by the Christian Democratic Party. SD used it in their stronghold region budget proposal: https://skane.sverigedemokraterna.se/files/2010/08/Budget-Region-Sk\%C3\%A5ne-2010.pdf
} 
Even from a demographic point of view, there is reason to question the high abortion rate. The seven politically correct parties in the Swedish Parliament consider, with the possible exception of the Christian Democrats, that our high abortion rates are quite in order. In Sweden, a woman gives birth to an average of 1.8 children. In order to maintain a stable population (without immigration), a required birth rate is slightly above 2 . The low birth rate will lead to significant strains on pensions and healthcare. The politically correct want to solve this by mass immigration from countries with high birth rate, that is, the Middle East and North Africa. As a Sweden Democrat I realise that such a policy will lead to a disastrous clash of cultures which will eventually break down our Sweden. Would it not be better pursuing a policy that lowers the abortion rate instead? (Björklund, 2009).

Gender equality (jämställdhet) is not given a specific place in SD's key policy document. It is not an area of policy but subordinated to the party's ideological framework. In an article under the heading 'Swedish gender equality equates women with cattle', an SD member of the party executive declares:

How much money and suffering gender equality ideology has consumed can be evaluated by looking at divorce rates, making visits to child and adult psychiatry wards, social services, schools, medical centres, addiction care and law enforcement (Sandstedt 2007).

For this party representative, gender equality is one of the roots of all societal conflicts. This quote shows how the SD is also a response to the successful Swedish women's movement 
(Walton, 2012) as well as towards social democratic and liberal policies that provide not only public support for combining work and family, but equalise, accept and explicitly support different family forms. SD is not the only voice in Sweden that would argue this way. There is a diverse array of conservative and neoconservative scholars, intellectuals and politicians who believe that gender equality has gone too far and who yearn for more strictly divided gender roles (Magnusson et al., 2008). What separates SD from many of these voices is the reasoning behind the criticism. Headlines like 'Another African rapist in Karlstad' (Orrenius, 2010), following racist representations of migrant men as patriarchal and violent against women, illustrate the means by which the SD aims to locate itself within the Swedish policy field regarding the intersection of race and gender.

However, gender equality is a difficult issue for culturally racist parties in the Nordic countries in general and for SD in particular (Berggren 2007; Gullestad 2002; Norocel 2010). On one hand, the party's ideological core is suspicious of gender equality and its connection with feminism; on the other, gender equality constructed as a Swedish national trait is often seen as a fundamental boundary between 'us and them'. Swedishness in this context is gender equality as a national characteristic, as highlighted in this opinion piece by Jimmie Åkesson, the SD party leader:

As a Sweden Democrat I see this [Islam and Muslims in Sweden] as our biggest foreign threat since World War II, and I promise to do everything in my power to reverse the trend when we go to the polls next year... 
...that leading representatives of the Muslim community will demand the implementation of Sharia law (Sharialagar) in Sweden; that the Swedish municipal health board (Landsting) would use taxes to circumcise (skära av förhuden) totally healthy young boys; that Sweden would have a higher level of rape and that Muslim men would be strongly represented among the rapists (förövare); that Swedish swimming clubs would introduce separate timetables for women and men, that Swedish municipalities would discuss the possibility of gender-segregated swimming education in schools (Åkesson 2009).

Representations of the Swedish Muslim population as a problem and as a threat to Swedish gender equality follow the same general discursive repertoire that is also present in mainstream political discourse: Swedish culture is secular, women-friendly and respects individuality, and Muslims are religious, patriarchal and living in collectivistic cultures (Gardell, 2010, Razack, 2004, Gullestad, 2002, Yegenoglu, 1998). SD justifies with the shared assumption within Swedish public discourse that it is those who belong to the nation who have the power and the right to decide over the process of achieving Swedishness. What is specific to the Sweden Democrats is that they focus on their right to exclude the other (instead of tolerating/educating/saving/exploiting the other). A key component of these arguments is the connection of the boundary between 'us and them' to polarisation processes in which the other is not only different but problematically different - they differ from what is considered normal (Hage, 1998). Another component of the activist stories, partly grounded view of themselves as normal, which was very present in our study, is the denial of racism. 


\section{Caring (racist) selves}

Despite their protestations against being called racist, our informants expounded worldviews which are plainly racist. All of them agree that migrants in general and Muslims in particular are a burden to the Swedish welfare state, because they do not work, they cheat and misuse the resources of the welfare state. They are also convinced that migrants in general and Muslims in particular are a threat to the Swedish nation, due to their background in patriarchal cultures and religions, and to their resistance to assimilation.

And then, recently, we visited X [neighbourhood] and then met with the police chief in $\mathrm{X}$ and he told me what the situation is there. And he confirmed exactly what I have said. Thus, there are very many families that certainly do not want to know anything about Sweden ... or Swedish society. They do not learn the language; they do not want to know about Swedish traditions or culture, even their obligations. They gladly accept the money and then they live a 'herd-life', you know...

That they are not racist is a message that is important to the informants, not only in relation to the party policies but in their understanding of their own identity. Our informants often come back to their (strong) self-esteem regarding their understanding of the personality traits that are needed to be SD; the pride they carry in the 'us' they create, in contrast to all the (Swedish) others who don't organise themselves (even though everyone thinks like 'us'). 
One way to understand SD's exclusionary racism is to imagine a Russian nesting-doll with endless small dolls in differnt shapes and forms but similar to one another popping out, one after another. Racist narratives while similar at the core, shift in both the target (Jews, Muslims, Blacks, migrants) and the content of the narrative (dangerous, a burden to the welfare state, patriarchal, impossible to assimilate, etc.). Many informants highlight the problem of migration in terms of the burden that migration is for the municipalities, whilst in the next breath saying that many of those who come here are not asylum-seekers and that most who come here exploit the system. Furthermore, the same informants group asylumseekers together with terrorists and criminals. Sometimes the informants talk about migrants referring to the entire category, sometimes about Negroes, Jews and Arabs, sometimes about nationality and sometimes (very rarely) about race, but often about Muslims (Mulinari \& Neergaard 2012b).

However, our informants share a specific form of racism predicated on their understanding of women, femininity and gender; a form of racism grounded in care, which distinguishes them from the broader public party rhetoric. A common story about the process of coming out as a Sweden Democrat is where the person wakes up and discovers that SD politicians are not as they are portrayed by the media. We use 'coming out' metaphors because the informants' narrative is structured in relation to a former self that embodied contradictory emotions but found it difficult to articulate them. 'Coming out' as an SD supporter or activist is, therefore, a kind of catharsis through which the new SD-self is (re)created. This is in line with SD female politicians' clear conversion stories, where the discovery that the evil is actually good is the essence of the story. In stories like this, the self is highlighted as having dared to transgress conventions and, through this, found a true capacity to develop their own caring self: 
It was before the elections. We were sitting there, all political parties there, in front of the podium. I had to sit next to a Sweden Democrat, and you've no idea, and everyone went like, 'Ohh, you're gonna sit next to.. Ohh!' They were really like, 'Ohh,' cold hands like this... So I just kind of sat there. But I realised he was really nice, there was absolutely nothing wrong with him and he didn't have all of these preconceived ideas, and he had really nice and proper ways. We spoke about our children. A normal conversation. I felt that he was really concerned about their future. That it was not only numbers for him. Why do people say that they're so horrible and, and that they're xenophobic and racists and... These people really care, they risk so much for others. Am I talking too much?

In this case, the informant had been working politically for another party, a party that she experiences as having become too 'politically correct' (informant's term) among other things, in its demarcation against the Sweden Democrats. It is the discovery that the SD representative is 'nice' that opens the door to her political career in the party. That SD is involved in politics not because its members are racist but because of their concern for others is a recurrent theme in our material. In the quote 'nice' is strongly linked to 'normal', and the nice is in opposition to holding racist ideas and arguments. Despite the efforts of postcolonial and race-critical scholars (Andersson and Molina, 2003, Hubinette and Lundström, 2010, Schierup and Ålund, 2011), the tendency to narrowly define racism in terms of biological 
racism continues to be strong in Sweden. When the informant argues that nice, normal people who care about their children cannot be horrible racists, she is identifying a central topic in the political debate: the transformation of the SD from a social movement with roots in Nazism ('horrible') to a parliamentary political party with an ethnopluralist platform ('acceptable') (Rydgren, 2007).

The quote below is re-produced here in its entirety because it is perhaps the most recurring type of comment in the interviews. In a series of conversations a coming-out discourse emerges that always begins with a description of the self as open and generous.

I've always been a person who is open to everybody. People who are Muslims or this and that or Chinese, it made no difference to me, because we're all just people. I've always thought that before. So I've tried to raise my kids [like that], but it hasn't been possible, because they have lived in a completely different world, where there's been a lot of gangs, where there's been a lot of assaults, where there's been a lot... and it's been the migrants. And it was probably then when I started to react and think that, 'But come on, Andrea - it's a nice thought, but it doesn't work that way in real life. It does not work for those that you care the most for.' I would be a bad mother if I did not acknowledge this. At the same time I started talking to the people coming from the former Yugoslavia, where they really hate each other now, and then I thought, 'Still, they lived in the same 
country, and they hate each other now. They're crude and racists.' There are a lot of people coming here, bringing this hate; they don't really want to live in harmony with us. It is neither good for them nor for us. And that's where I feel strongly about doing something.

There are two basic explanations as to why the informant changed her view of people with other backgrounds. On the one hand, her experience as a mother and what she perceives as her equality ideology collides with her children's experiences (of gangs of immigrants). On the other hand, she explains her racism by the racism of 'others'. It is 'they' who come here bringing hate and prejudice, thereby forcing the informant to change her ideology which, according to the informant herself, is not sustainable 'in real life'. In her account, racism is a cultural product that has been brought to Sweden by immigrants and forces Swedes who have previously followed an equality ideology to think differently. In other words, it is the migrants' fault that SD is forced to think the way they do. In addition, because she wants to be a good mother, or actually because the migrants and migration hinder her from being a good mother, she becomes a member of an organized political party. At the crossroads between the culturally racist politics of the SD and gender, a racist maternalism evolves (van der Klein et al., 2012, Koven and Michel, 1993) where care includes everybody, even those who are one of the party's central targets. 
Female politicians in SD want to develop a positive identity in which their involvement in the party is explained by their concern for others, not by, as one informant articulated it, 'any ideology of hatred; it is because we love, not because we hate, that we are in SD'.

I have always - even as a child, so to speak - if there was someone who wasn't accepted or bullied, I tried to take care of them in any way, and in that I haven't allowed myself to become affected by the surrounding world, what they thought, but I have followed my own inner voice when it comes to fighting for and supporting the little man...To protect and to care for those that are vulnerable and in need of help. But that naturally leads to the issues of caring for our own as well.

From her story emerges a self-image of an enthusiastic person who is passionate about social justice issues, and whose sole purpose is to protect the vulnerable human being'. In this conception of the world, SD adherents belong to a party that wants to allocate resources and include those who are excluded. Scholarship on citizenship and nationhood has identified how the construction of who is a citizen is at the core of social policy visions in a globalised world (Lewis, 2000). The tension is evident in the definition of who deserves care; it is in the shift from care for all, to care 'for our own' that the ideology of the party can be seen. This form of caring racism reappeared in a series of interviews, connected to arguments that expand the care for our own towards forms of inclusive (racist) care. This is especially present in the argument that SD's policies, which are often criticised for being racist, aim to protect migrants from the Swedish refugee policy: 
I don't have anything against refugees, because I am myself a second-generation migrant. It's about this flow of refugees that we have - we've taken on too many refugees. We can't keep track of it. And this has already been going on for twenty years. We're seeing how the country is starting to fall apart - welfare, our welfare state we once created. And it's not the refugees' fault, but it's a political failure. And that's why I've become involved in this, because I want to change it. We have segregation, we have cultural clashes, we have ethnic tensions and then we have these enclaves where immigrants settle in one area and do not become part of Swedish society. And this has been allowed to happen. And so I repeat: we are the ones who haven't managed it properly here in Sweden. We've just let this pass without doing anything. And the migrants themselves also think this has become a problem. They have, when they've arrived here they've gotten problems with their children. Many of our migrants have fallen into criminal activities, as have many of our young people. But we must tackle the problem, and it's hard when it keeps accelerating all the time, and you don't do anything about it. The SD is the one to speak out, the only one who cares.

This long quotation is an illustration of the form of racist care the informants convey. It is interesting to see how this informant oscillates between being Swedish and being a migrant. 
Her story is founded on three basic assumptions: the first is a sort of variant on the threat of disaster ( too many immigrants, ethnic enclaves'); the second is legitimation through the presence of migrants as a category (I'm an immigrant myself, I have migrant friends, migrants personally agree with me') often used by the SD to respond to criticism regarding racism. The third is a systematic difference between us (Swedes developing a flawed policy) and them (migrants who come here) where 'they' are regarded as a monolithic group without individuality, and where 'we' have responsibility for 'our' migrants. The argument that the SD also cares for the future of migrant families and their generational conflicts, is an important frame of the particular forms of care racism:

So the biggest part that we as a party focus on is in fact the immigration issue and how it has undermined and eroded the country. A lot has been set aside because of these expenses that are connected to an immigration that has been horrible both for those who come here and those who live here. It's not humane, any of this.

The last two quotes highlight what could be seen as an ethnopluralist (Rydgren, 2007) discourse. Care may be extended to the racialised other through arguing that their migration to Sweden (while of course not being good for Sweden and the 'Swedes') is also bad for the migrants themselves. In this sense care racism is also formulated as helping migrants by sending them back to their 'true' home. 
Our informants' view of care creates two variants of what we conceptualise as care racism.

The first and dominant form is caring selves, in which a racialised version of the (Swedish) self is constructed based on the aggregation of how the family is viewed. A second version of caring racism is linked to what we see as an ethnopluralist understanding. Here caring also extends to the racialised other, albeit in the form of caring that they return to their home country, for their own good. Whereas the first form of caring racism has been discussed in general terms, for instance through the analysis of welfare chauvinism, what we consider to be our contribution is in the consideration of its gendered forms. In addition, we argue that a second variant of caring racism facilitates being an exclusionary racist by formulating it as a form of caring for the racialised other.

Care is salient for two reasons. The first is the centrality of the notion of care in the Nordic welfare states in general, and in particular, among feminist scholars exploring the subordinated position of women within a gender-segregated labour market doing care work (Bergqvist, 1999). The other is the existential need, so present in what our informants told us, to explain their participation in the party being due to the positive value of caring, rather than the negative value of racism.

An often taken-for-granted aspect in feminist scholarship has been the normative 'good' in care, whereas the focus has been on avoiding (over)exploitation in care work. Our angle, inspired by postcolonial feminism, is slightly different. Social anthropologist Uma Narayan (1995) argues that while contemporary care discourses focus on acknowledging human needs and relationships, there is a need to identify a colonial care discourse that enables colonisers to construct themselves as superior. The author asserts that thinking about care discourses in colonial contexts illuminates the roles it has historically played in legitimating relations of 
power (see also Ware, 2008). Cultural critic Sara Ahmed further explores these connections between feelings and racism in the following words:

How has politics become a struggle over who has the right to name themselves as acting out of love? What does it mean to stand for love by standing alongside some others and against other others? (Ahmed, 2003)

The concept of caring racism follows in this postcolonial feminist tradition by identifying care as a floating signifier successfully appropriated by the racist party. Can racism be caring? Our informants' answer to the question is yes. We agree with them on a number of issues. Racist parties provide an epistemic community where people care for each other. Members of racist parties use their time and resources for what they think are the common good, the caring of 'their' people. Caring is the promise of the Swedish 'people's home' that the Social Democratic regime failed to provide. Caring creates subject positions both for women (as caring mothers) and for men (as protectors and caring fathers of the nation). Furthermore, SD the SD supporters in our study construct their exclusion and separation from the racialised other, not only as caring for the self, for our own, but also as caring for them, preserving their purity as the 'other'.

\section{Concluding remarks}

The growing body of research on Populist Radical Right Parties has gone to some lengths to avoid naming these parties racist. Inspired by feminist, antiracist and postcolonial theories, and by our own experiences as non-white researchers, we argue in contrast that these parties should not only be named as cultural racists, but that they are not aberrations, polluting an otherwise non-racist liberal democratic Europe. We see the Sweden Democrats and similar 
European parties as extreme versions within an internal European dynamic, in which racialisation and cultural racism are present.

We have tried to show how cultural racism is linked to an ambiguous position concerning feminism and gender equality. In one sense, cultural racism walks hand in hand with a reactionary and anti-feminist understanding of gender equality. In another sense, and in subordinating gender politics to cultural racism, gender equality is named as something 'Swedish' against the migrant other, especially Muslims. This paradoxical position is probably a hallmark of this type of culturally racist party in a Nordic context, in which gender equality, albeit critical of feminism, becomes an important element in constructing nationalism in a culturally racist praxis.

A large part of the article centres on care as a prism through which to grasp cultural racism. Our informants framed two forms of care discourses. On the one hand, a caring racism focused on nurturing a 'we' defended against the migrant other. However, a more inclusive form of caring racism was also found, in which ethnopluralism was made visible. Protecting Sweden against migrants was not only a way of caring for the 'Swedes', women members of the Sweden Democrats argued, but also a way of caring for the migrants themselves (and their cultures).

Thus, inspired by antiracist and postcolonial feminist analysis, we argue that narratives about care, which have often been strongly linked to Scandinavian feminist analyses of a normatively positive praxis of women's care work, should be rethought in a way that also allows for problematic facets of care. 


\section{References (Harvard)}

Adkins, L. 2001. Cultural feminization: 'Money, Sex and Power' for women. Signs. Journal of Women, Culture and Society, 26, 669-682.

Ahmed, S. 2003. In the name of love. Bordelands, 2, 1-41.

Andersson, R. \& Molina, I. 2003. Racialization and Migration in Urban Segregation Processes. Key issues for critical geographers. In: Öhman, J. \& Simonsen, K. (eds.) Voices from the North - New Trends in Nordic Human Geography. London: Ashgate.

Balibar, E. 1991. Is there a 'Neo-Racism'? In: Balibar, E. \& Wallerstein, I. (eds.) Race, Nation, Class: Ambiguos Identities. London: Verso.

Barker, M. 1981. The New Racism: conservatives and the ideology of the tribe. London, Junction Books.

Berggren, Erik. 2007. Danish Xenophobia - Power Logic in Motion. In Berggren, E., LikićBrbrić, B, Toksöz, G. \& Trimikliniotis, N. (eds.) Irregular migration, informal labour and community: a challenge for Europe, edited by Maastricht: Shaker

Bergqvist, C. 1999. Equal democracies? gender and politics in the Nordic Countries. Oslo, Scandinavian Univ. Press in co-operation with the Nordic Council of Ministers.

Betz, H.-G. 2005. Populist Parties of the Right. In Rydgren, J. (ed.) Movements of Exclusion. Radical Right-wing Populism in the Western World. Hauppauge, NY: Nova Science.

Bhavnani, K.-K. 2001. Feminism and 'Race'. Oxford University Press, Oxford.

Blee, K. \& Kenny, L. 2000. White on white; Doing my homework. In: Winddance Twine, F. \& Warren, J. (eds.) Racing research, researching race: methodological dilemmas in critical race studies. New York: New York University Press. 
Blee, K.M. 2007. Ethnographies of the Far Right. Journal of Contemporary Ethnography, 36, 119-128.

Castles, S. \& Kosack, G. 1973. Immigrant Workers and Class Structure in Western Europe. London, Oxford University Press.

Deland, M. \& Westin, C. (eds.) 2007. Brunt. Nationalistisk och nazistisk mobilisering i vår närmaste omvärld under efterkrigstiden. Stockholm: Atlas.

Essed, P. 2001. Multi-identifictions and transformations: Reaching Beyond Racial and Ethnic Reudctionisms. Social Identities, 7, 493-509.

Feldman, D. 2011. Why the English Like Turbans: Mulitcultural Politics in British History. In: Feldman, D. \& Lawrence, J. (eds.) Structures and Transformations in Modern British History. Cambridge: Cambridge University Press.

Fennema, M. 1997. Some Conceptual Issues and Problems in the Comparison of AntiImmigrant Parties in Western Europe. Party Politics, 3, 473-492.

Gardell, M. 2010. Islamofobi. Stockholm, Leopard.

Gavanas, A. 2010. Who cleans the welfare state? Migration, informalization, social exclusion and domestic services in Stockholm. Research Report. Stockholm: Institute for Futures Studies.

Gilroy, P. 2004. After empire: melancholia or convivial culture? London, Routledge.

Gullestad, M. 2002. Invisible fences: Egalitarianism, nationalism and racism. The Journal of the Royal Anthropological Institute, 8, 45-63.

Hage, G. 1998. White Nation: Fantasies of White Supremacy in a Multicultural Society. Annandale, Pluto Press. 
Hellström, A. \& Nilsson, T. 2010. 'We Are the Good Guys': Ideological Positioning of the Nationalist Party Sverigedemokraterna in Contemporary Swedish Politics. Ethnicities, $1,55-76$.

Hubinette, T. \& Lundström, C. 2010. Sweden after the Recent Election: The Double-Binding Power of Swedish Whiteness through the Mourning of the Loss of 'Old Sweden' and the Passing of 'Good Sweden'. NORA-Nordic Journal of Feminist and Gender Research. 19, 42-52.

Koonz, C. 1987. Mothers in the fatherland: women, the family, and Nazi politics. New York, St. Martin's Press.

Koven, S. \& Michel, S. (eds.) 1993. Mothers of a new world: maternalist politics and the origins of welfare states. New York: Routledge.

Lewis, G. 2000. 'Race', Gender, Social Welfare. Encounters in a Postcolonial Society. Cambridge, Polity Press.

Lewis, G. 2006. Imaginaries of Europe: Technologies of gender, economies and power. The European Journal of Women's Studies, 13, 87-102.

Lutz, H. 2011. The new maids: transnational women and the care economy. London, Zed.

Magnusson, E., Rönnblom, M. \& Silius, H. (eds.) 2008 Critical studies of gender equalities: Nordic dislocations, dilemmas and contradiction. Göteborg: Makadam.

Martin, P.Y. 2001. 'Mobilizing Masculinities': Women's Experiences of Men at Work. Organization 8, 587-618. 
Mella, O. \& Palm, I. 2013. Mångfaldsbarometern 2013. Uppsala: Uppsala University, Department of Sociology.

Miles, R. 1987. Capitalism and unfree labour: anomaly or necessity? London, Tavistock.

Mudde, C. 2000. The Ideology of the Extreme Right. Manchester, New York, Manchester University Press.

Mudde, C. 2007. Populist Radical Right Parties in Europe. Cambridge, Cambridge University Press.

Mulinari, D. \& Neergaard, A. 2012b. The Sweden Democrats, racisms and the construction of the Muslim threat. In MORGAN, G \& POYNTING, S (eds.) Global Islamophobia: Muslims and Moral Panic in the West. London: Ashgate

Mulinari, D. \& Neergaard, A. 2012a. Violence, Racism, and the Political Arena: A Scandinavian Dilemma. NORA - Nordic Journal of Feminist and Gender Research 20 (1):12-18.

Narayan, U. 1995. Colonialism and Its Others: Considerations On Rights and Care Discourses. Hypatia 10, 133-140.

Norocel, O.C. 2010. Constructing radical right populist resistance: metaphors of heterosexist masculinities and the family question in Sweden. Nordic Journal for Masculinity Studies, 5, 169-183.

Orrenius, N. 2010. Jag är inte rabiat, jag äter pizza: en bok om Sverigedemokraterna. Stockholm, Månpocket.

Perry, B. 2001. In the Name of Hate: Understanding Hate Crimes. London, Routledge.

Phizacklea, A. 2004. Migration Theory and Migratory Realities: a Gendered Perspective. In: JOLY, D. (ed.) International Migration in the New Millennium. London: Ashgate. 
Razack, S.H. 2004. Imperilled Muslim Women, Dangerous Muslim Men and Civilised Europeans: Legal and Social Responses to Forced Marriages. Feminist Legal Studies, $12,129-174$.

Rose, J. 2005. Femininity and its discontents. Feminist Review, 80, 24-43.

Rydgren, J. 2005a. Is extreme right-wing populism contagious? Explaining the emergence of a new party family. European Journal of Political Research, 413-437.

Rydgren, J. 2005b. Movements of exclusion: radical right-wing populism in the Western world. New York, Nova Science.

Rydgren, J. 2007. The Sociology of the Radical Right. Annual Review of Sociology, 33, 241262.

Sandstedt, M (2007)

http://www.sdkuriren.se/blog/index.php/margareta/2007/12/10/den_svenska_jamstalld heten_likstaller_kv $071210(091027$

Schierup, C.-U. \& Ålund, A. 2011. The end of Swedish exceptionalism? Citizenship, neoliberalism and the politics of exclusion. Race \& Class, 53, 45-64.

Sverigedemokraterna (2005) Sverigedemokraternas principprogram http://www.sverigedemokraterna.net/asikt_text.php?action=fullnews\&id=317 (091026)

Walton, S.J. 2012. Anti-feminism and Misogyny in Breivik's 'Manifesto'. NORA. Nordic Journal of Feminist and Gender Researach, 20, 4-11.

Van der Klein, M., Plant, R.J., Sanders, N. \& Weintrob, L. 2012. Maternalism Reconsidered. Motherhood, Welfare and Social Policy in the Twentieth Century. Oxford, Berghahn Books. 
Ware, V. 2008. Towards a Sociology of Resentment: A Debate on Class and Whiteness. Sociological Research Online, 13, 9.

Yegenoglu, M. 1998. Colonial Fantasies: Towards a Feminist Reading of Orientalism. Cambridge, Cambridge University Press.

Yuval-Davis, N. \& Marfleet, P. (eds.) 2012. Secularism, Racism and the Politics of Belonging. London: Runnymede Perspectives. 